This is a preprint of an article accepted for publication in The Chemical Record (C) Copyright 2009 John Wiley \& Sons, Inc, and the Japan Chemical Forum.

DOI: $10.1002 /$ tcr.200900001

\title{
Antimalarial Natural Products of Marine and Freshwater Origin
}

Karl Gademann* and Joanna Kobylinska

Chemical Synthesis Laboratory (SB-ISIC-LSYNC)

Swiss Federal Institute of Technology (EPFL)

CH-1015 Lausanne

Switzerland

*correspondence to:

Email: karl.gademann@epfl.ch

Phone: +41216939315

Fax: + 41216939700

http://lsync.epfl.ch 


\begin{abstract}
This review highlights recently discovered antimalarial natural products from marine and freshwater sources described in the literature from 2006 to 2008. The structures as well as bioactivities of compounds against the malaria parasites such as Plasmodium falciparum are discussed, including for example agelasine, xestoquinone, alisiaquinone, crambescidin, venturamide, dragomabin, gragonamide, viridamide, salinosporamide, chaetoxanthone, nodulisporacid, tumonoic acid, girolline, oroidin, nostocarboline, aerucyclamide and microcylamide 7806 and its revised structure. Synthetic derivatives of natural products are presented including plakortin, isoaaptamine, curcuphenol, pseudopyronine, manzamine and nostocarboline. Consequences of these discoveries for the development of novel natural product agents against malaria are discussed.
\end{abstract}




\section{Biographical Sketch}

Karl Gademann (1972) was educated at ETH Zürich and Harvard University (PhD with Prof. Dr. Dieter Seebach, postdoctoral studies with Prof. Dr. Eric N. Jacobsen, Habilitation associated with Prof. Dr. Erick M. Carreira). He is currently an assistant professor at the Swiss Federal Institute of Technology (EPF Lausanne). He has published over fifty publications, holds two patents and received several awards including the Latsis Prize, Lilly Lecture Award, the Schläfli award of the Swiss Academy of Sciences, and, most recently, the Liebig Lectureship of the German Chemical Society. He was awarded the European Young Investigator grant related to natural product synthesis research. His research interests include the synthesis and chemical biology of natural products.

Joanna Kobylinska was born in 1975 in Skarzysko-Kamienna, Poland. She studied organic chemistry at the Technical University of Wroclaw and carried out her Diploma thesis in 2000 in the group of Prof. Dr. Jacek Skarzewski, working on catalytic enantioselective oxidations. She completed her $\mathrm{PhD}$ studies in 2004 in the group of Prof. Dr. Manfred Schlosser at the EPFL (Lausanne, Switzerland) dealing with the organic synthesis and regioselective functionalization of fluorinated aromatics. Currently, she is carrying out postdoctoral studies in the group of Prof. Dr. Karl Gademann at the EPFL working on surface functionalization and modifications. 


\section{Introduction}

Malaria constitutes the most threatening parasitic infection in humans. Each year, between 300 to 500 million new clinical cases are reported by the world health organization, ${ }^{1}$ resulting in annual deaths of about one million people, ${ }^{2}$ of which threequarters of the fatalities are children below 5 years of age. ${ }^{3}$ The most exposed continent is Africa, but also South-east Asia, Oceania, and Central and South America are under severe threat. Among the most affected countries are developing nations, which suffer from a weakly developed health care system.

There are four species of Plasmodium infecting humans: P. falciparum, P. vivax, $P$. ovale and $P$. malariae, but most of the malaria cases are caused by the protozoan parasite P. falciparum. ${ }^{4}$ The parasite is transmitted by Anopheles mosquitos, and therefore malaria can be controlled to some extent by conventional prevention strategies such as mosquito repellents, mosquito traps, insecticides or biological control. The introduction of efficient vaccines is still problematic, despite recent progress in this area. ${ }^{5}$ As a direct consequence, the treatment of choice remains parasite chemotherapy with small molecule drugs both of natural origin or synthetics. 6, 7 In parallel, resistance of the malaria parasite to commonly used drugs such as quinine, chloroquine and mefloquine is emerging, ${ }^{8}$ which results is an urgent need to develop new drugs against this disease. Also, an additional option for treatment, which implies reduction of the risk of resistance, offers the combination of two antimalarial drugs. Examples of such drug combinations are the artemisininamodiaquine and the artemether-lumefantine combination (Coartem). ${ }^{9}$ 


\section{Antiplasmodial Agents of Marine and Freshwater Origin}

The marine environment, taking more than $70 \%$ of the Earth's surface, is a rich source of both biological and chemical diversity. As a consequence, such aqueous environments harbor new compounds with great potential as pharmaceuticals, nutritional supplements, cosmetics and agrochemicals. ${ }^{10}$ Many life forms in the marine environment such as algae, sponges, corals, ascidians and fungi have been investigated for their natural product content. ${ }^{11-13}$ Many structurally and pharmacologically important substances have been isolated with novel antimicrobial, antitumor, anti-inflammatory, antimalarial, antibiotic or antifouling properties, and they are described in several excellent reviews that have appeared in recent years. ${ }^{14-24}$ In the current review, we give an overview of the bioactive metabolites recently isolated from marine organisms that have shown antiplasmodial activity and discuss their pharmacological potential. In addition, since some freshwater organisms have been found to populate both freshwater and marine environments (e.g. cyanobacteria), are found in brackish mixed environments, or are washed out into the ocean by rivers and streams, we have chosen to include examples from both aquatic domains.

While we do not claim completeness, research efforts published between 2006 and 2008 are discussed in the following chapters.

Several alkaloids were identified from marine sources in the last years. A survey of different invertebrates was conducted by Mendiola et al., ${ }^{25}$ in order to classify these sources for antiplasmodial activity. Seven extracts from different marine species, three species of Chordata, two species of Echinodermata, one species of Cnidaria and one species of Porifera, collected on the northwest Cuban coast from Havana to Puerto Esperanza were reported to display moderate antimalarial activity. ${ }^{25}$ Among them, three ascidians produced in vitro $\mathrm{IC}_{50}$ values lower than $30 \mu \mathrm{g} / \mathrm{ml}$, and in vivo, the crude extracts caused partial reduction of Plasmodium berghei parasitaemia in mice. ${ }^{25}$ Alkaloids and polyketides were found to be the major substances with antimalarial activity isolated from chordata, but the studied aqueous extracts of three ascidians were mixtures of compounds.

Although agelasidae sponges have been widely investigated, they still represent a source of new marine metabolites. ${ }^{10}$ Three new diterpene alkaloids, agelasine $\mathbf{J}(\mathbf{1})$, agelasine K (2), and agelasine L (3), were recently isolated from the marine sponge 
Agelas cf. mauritiana from the Solomon Islands. ${ }^{26 a}$ Agelasine J (1) was obtained previously by Nakamura et al. by semisynthesis from agelasine A or B under acidic conditions. ${ }^{26 \mathrm{~b}}$ All three compounds displayed moderate activity on P. falciparum with $\mathrm{IC}_{50}=6.6,8.3$ and $18 \mu \mathrm{M}$ for agelasines $\mathrm{J}, \mathrm{K}$ and $\mathrm{L}$, respectively, and a low cytotoxicity on MCF7 cells with $\mathrm{IC}_{50}$ values of 33,30 and $80 \mu \mathrm{M}$, was determined. The molecular target of these substances was not yet investigated. ${ }^{26 a}$

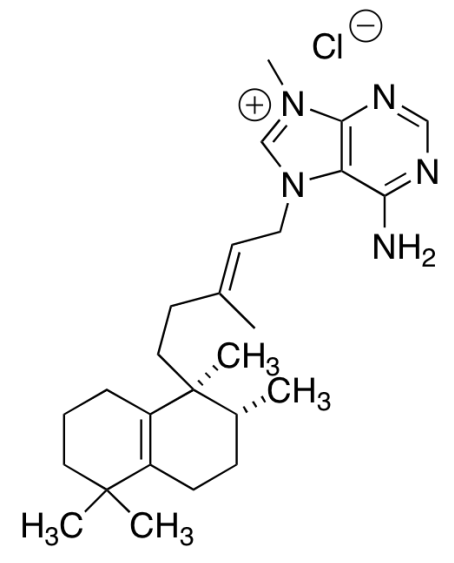

1

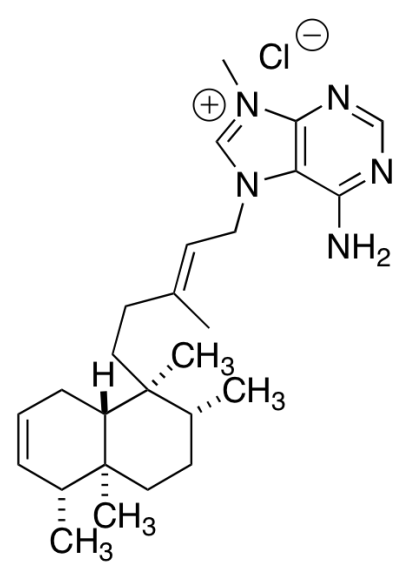

2

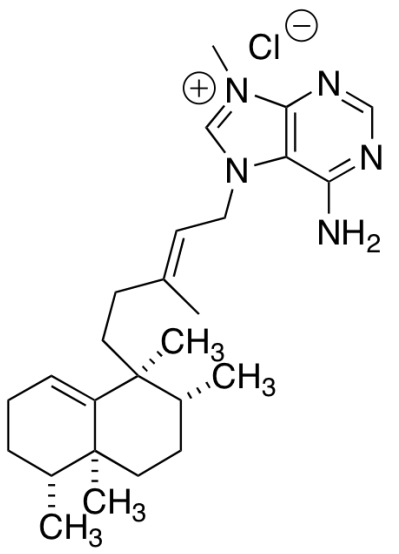

3

From a Mycophora sp. Sponge, crambescidin 800 (4) was isolated, ${ }^{27}$ which had been previously reported, ${ }^{28}$ and few analogues had been prepared. Crambescidin 800 (4) showed in vitro activity against chloroquine(CQ)-resistant FCR3 P. falciparum $\left(\mathrm{IC}_{50}\right.$ $=240 \mathrm{nM})$ and CQ-sensitive 3D7 strains, $\left(\mathrm{IC}_{50}=160 \mathrm{nM}\right)$. The most active analogue 5 had in vitro activity against $P$. falciparum strain 3D7 comparable to quinine as well, but slightly less than that of crambescidin $800\left(\mathrm{IC}_{50}=490 \mathrm{nM}\right) .{ }^{27}$ The mode of action has not been investigated, but similar compounds have been shown to be channel blockers or ATPase inhibitors. $^{27}$ 


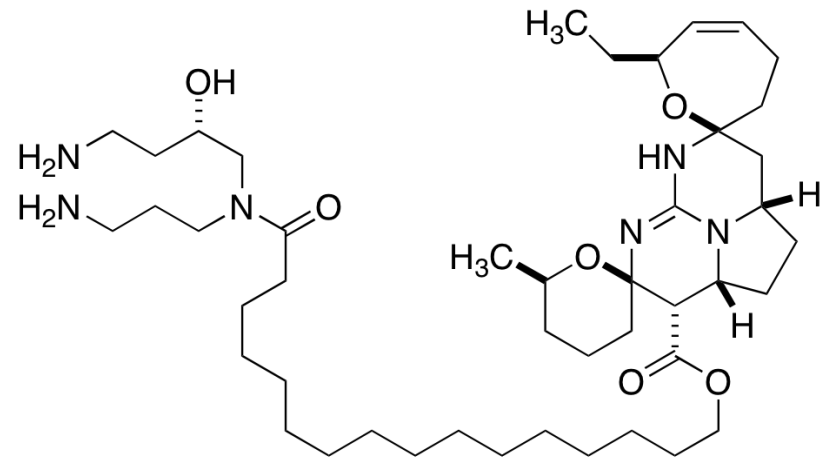

4

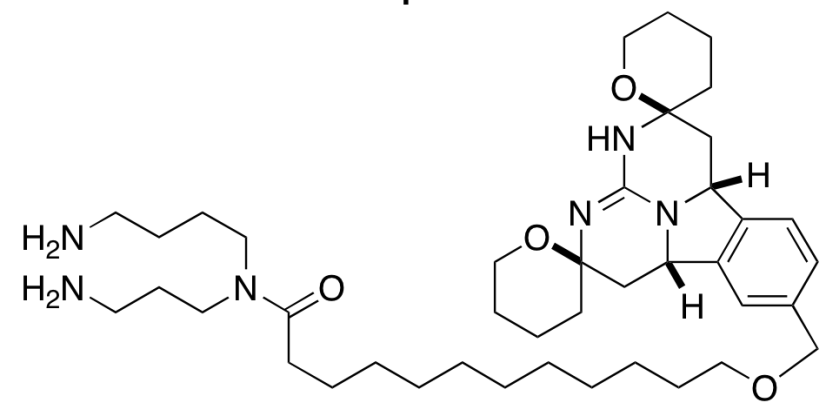

5

Novel isoaaptamine analogues ${ }^{29}$ were prepared by coupling acyl halides to the C9 position of isoaaptamine (6), first isolated from a sponge of the genus Suberites by Fedoreev, ${ }^{30}$ later by two other groups from the sponge Aaptos aaptos, ${ }^{31,32}$ and recently from a sponge belonging to the genus Hymeniacidon. ${ }^{33}$ The compound $\mathbf{6}$ displayed remarkable activity against the W2 clone and good activity against the D6 clone of $P$. falciparum, with an $\mathrm{IC}_{50}$ values of 380 and $1100 \mathrm{ng} / \mathrm{mL}$, respectively. All nineteen synthesized derivatives resulting from various acyl halides coupled at C9 position of isoaaptamine (6) have had a negative impact on the activity against the W2 clone. However, the activity against the D6 clone in many derivatives increased, and the most potent were compounds 7 and 8, with $\mathrm{IC}_{50}=230$ and $240 \mathrm{ng} / \mathrm{mL}$, respectively. ${ }^{29}$<smiles></smiles>

6<smiles>COc1cc2c(OC(=O)c3ccc(C)cc3)c3c1C(=NC=C2)C=CN3C</smiles>

7<smiles>COc1cc2c(OC(=O)c3ccc(C(C)(C)C)cc3)c3c1C(=NC=C2)C=CN3C</smiles>

Recently Tasdemir et al. $^{34}$ reported isolation of six pure metabolites and some 
complex fatty acid mixtures (FAMA-FAMG) from the Turkish marine sponge Agelas oroides which showed promising PfFabI inhibitory and antiplasmodial activity. Among the metabolites, $(E)$-oroidin (9) was isolated as free base and identified as the most potent enzyme PfFabI inhibitor with $\mathrm{IC}_{50}=0.77 \mu \mathrm{M}$. The kinectic analysis revealed an uncompetitive binding mechanism with respect to substrate and cofactor, indicating that the compound 9 is exclusively binding to the enzyme-substrate complex or enzyme-cofactor complex. ${ }^{34}$ This mechanism is identical to the one observed for triclosan towards FabI of various species. ${ }^{35,} 36$ Oroidin base (9) was assayed for its in vitro inhibitory activity on multidrug resistant $\mathrm{K} 1$ strain of $P$. falciparum and it exhibited an $\mathrm{IC}_{50}$ value of $3.9 \mu \mathrm{g} / \mathrm{mL}$ in the whole cell parasite assays. Oroidin (9) is a condensation product of the imidazol portion, 3-amino-1-(2aminoimidazoyl)-prop-1-ene (10), which has no effect on PfFabI, but has unspecific effect on the malaria parasite, and 4,5-dibromopyrrole-2-carboxylic acid 11, which is not toxic, but has limited antimalarial and $\mathrm{P} f \mathrm{FabI}$ inhibition activities. A previous report $^{37}$ described oroidin (as TFA salt) to be inactive towards the D6 and W2 strains of $P$. falciparum, however, a more recent study reported a moderate antimalarial effect with an $\mathrm{IC}_{50}=1.2 \mu \mathrm{g} / \mathrm{mL}^{38}$

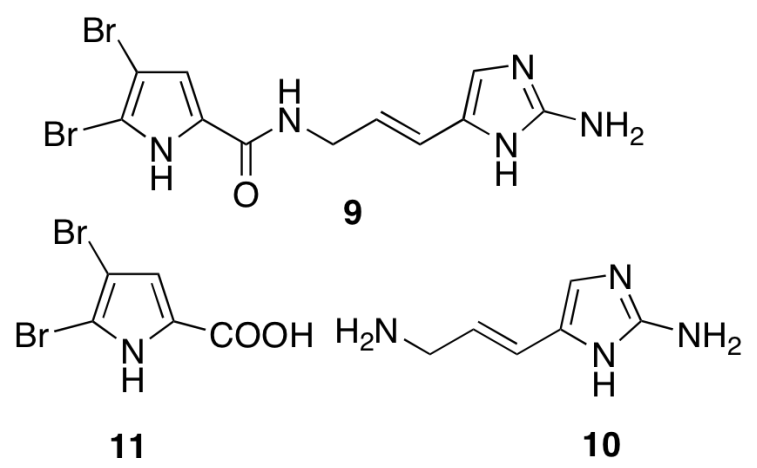

Benoit-Vical and co-workers ${ }^{39}$ evaluated the effects of a natural product girolline (12) and some of its synthetic analogues in vitro and in vivo against $P$. falciparum and $P$. vinckei petteri, respectively. This 2-aminoimidazol derivative was originally isolated from a New-Caledonian sponge Cymbastela cantharella, ${ }^{40}$ and this compound was demonstrated for its antitumor properties. ${ }^{41-43}$ More recently the compound $\mathbf{1 2}$ has been also isolated from another species of the marine sponge Axinella brevistyla collected in western Japan. ${ }^{44}$ 
<smiles>NCC(Cl)[C@H](O)c1cnc(N)[nH]1</smiles>

The $\mathrm{IC}_{50}$ value of girolline (12) on the CQ-resistant strain FcM29 was determined to be $130 \mathrm{nM}$, and with artemisinin or chloroquine the compound inhibited parasitic growth by $100 \%$. Several synthetic analogues were shown to possess $\mathrm{IC}_{50}$ values higher than $50 \mu \mathrm{M}$. Girolline (12) showed also very high activity in an in vivo Plasmodium vinckei petteri assays, and even although the compound displays some toxicity, ${ }^{42}$ it might considered as a natural compound with very promising activity against malaria. ${ }^{39}$ The mode of action of this compound is debated in the literature, and Benoit-Vical et al. suggest its mechanism to be related to the inhibition of protein synthesis. $^{39}$

Our group has recently isolated nostocarboline (13), an acetyl- and butyrylcholinesterase, and trypsin inhibitor from the cyanobacterium Nostoc $78-12 \mathrm{~A} .{ }^{45-47}$ The compound itself inhibits Plasmodium with high selectivity in nanomolar concentrations, and additionally, dimerization of nostocarboline leads to very potent and selective antiplasmodial agents. ${ }^{48}$ Nostocarboline (74) was synthesized starting from norharmane via chlorination at C-6 and methylation according to published procedures. $^{45,46}$

Scheme 1. Preparation of nostocarboline (13) from norharmane. Reagents and conditions: (a) $\mathrm{NaOCl}, \mathrm{EtOH}, 0{ }^{\circ} \mathrm{C}, 30 \mathrm{~min}$, then rt, $5 \mathrm{~h}, 75 \%$; (b) $\mathrm{CH}_{3} \mathrm{I}, i-\mathrm{PrOH}$, reflux, $4 \mathrm{~h}, 94 \%$.<smiles>C[13c]1ccc2c(c1)[nH]c1ccc(Cl)cc12</smiles>

6-Cl-norharmane was also the starting material for the synthesis of ten nostocarboline symmetrical homo-dimers of general formular 14. Alkenyl, alkynyl, aryl, biaryl and alkyl linkers of various lenghts were employed for the corresponding dimers, which 
were obtained in a two-step process and in good yields $(60-95 \%)$.

Nostocarboline (13) as well as dimers such as 16-20 were evaluated against $P$. falciparum K1. Nostocarboline (13) displayed antimalarial activity against the K1 strain with an $\mathrm{IC}_{50}=194 \mathrm{nM}$, and in addition it showed very weak cytotoxicity $(>100$ $\mu \mathrm{M})$, giving rise to a 600 fold selectivity of Plasmodium over rat myoblast L6 cells. The best results against $P$. falciparum were obtained for dimers with long and flexible linkers, and compounds 16-20 displayed $\mathrm{IC}_{50}$ values below $100 \mathrm{nM}$, and the most active compound 19 containing a $\left(\mathrm{CH}_{2}\right)_{10}$ linker displayed an $\mathrm{IC}_{50}=14 \mathrm{nM}$ against $P$. falciparum K1. Cytotoxicity against the L6 rat myoblast cell line was determined as well, and the values varied between 5-60 $\mu \mathrm{M}$. Cytotoxicity increased with linker length, thus decreasing selectivity for longer linkers. Compounds $\mathbf{1 6}$ and $\mathbf{1 7}$ with five and six atom linkers are considered optimal in this series. Compound $\mathbf{1 6}$ displayed high potency $\left(\mathrm{IC}_{50}=18 \mathrm{nM}\right)$ and an excellent selectivity of $>2500$-fold against the L6 cell line. The mode of action of these compounds is currently under investigation.
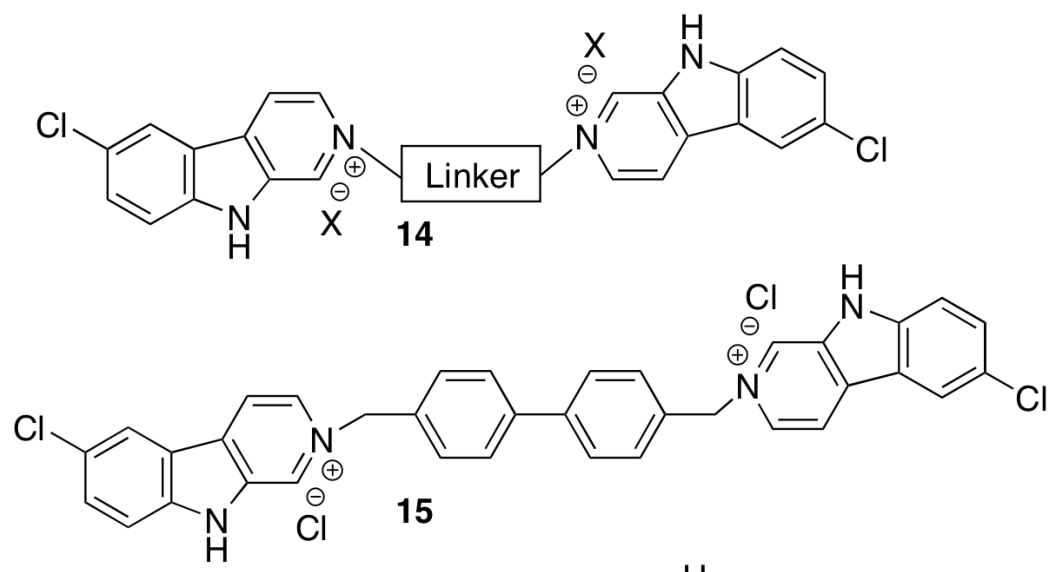<smiles></smiles>

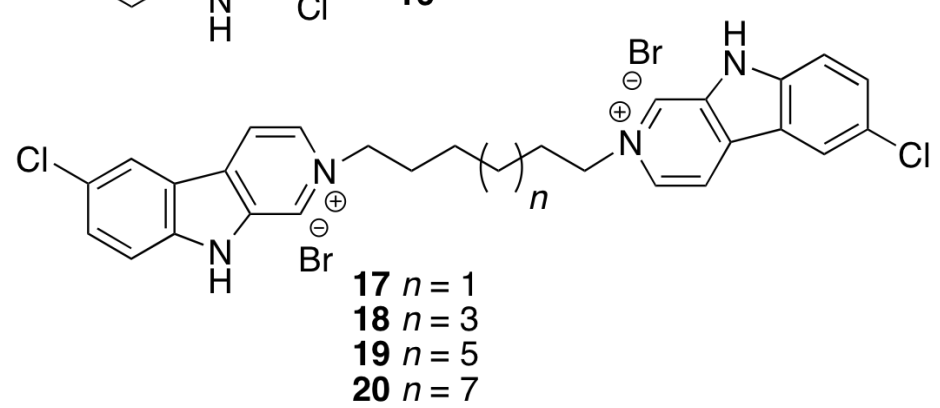


A remarkable example of a marine compound with potential activity against $P$. falciparum is manzamine A (21), a unique beta-carboline alkaloid. The compound was first isolated from the Okinawan sponge of the genus Haliclona, ${ }^{49}$ since then more than 60 manzamine and related alkaloids have been isolated from 16 species of sponges belonging to nine different genera. ${ }^{50,51}$ More than $90 \%$ of the asexual erythrocytic stages of Plasmodium berghei were inhibited after a single intraperitoneal injection of manzamine A (21) into infected mice. Such suppressive activity is comparable to that of chloroquine and superior to that of artemisinin at the same dose. $^{52}$

One of the common manzamine alkaloids is 8-hydroxy-manzamine A (22) that has been isolated from sponges of the genera Amphimedon, Xestospongia, Acanthostrongylophora, and Pachypellina. ${ }^{53-55}$ Despite highly promising antimalarial activity, toxicity remains a major problem with respect of the potential for alkaloids such as $\mathbf{2 1}$ and $\mathbf{2 2}$ as drugs.

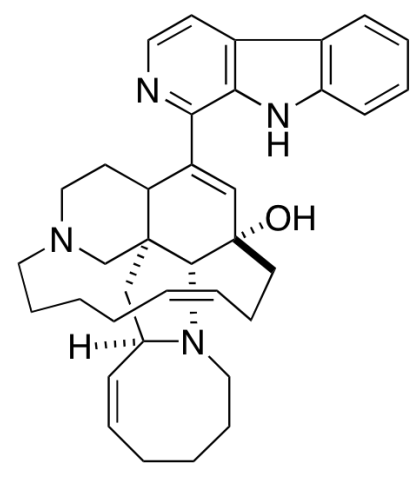

21

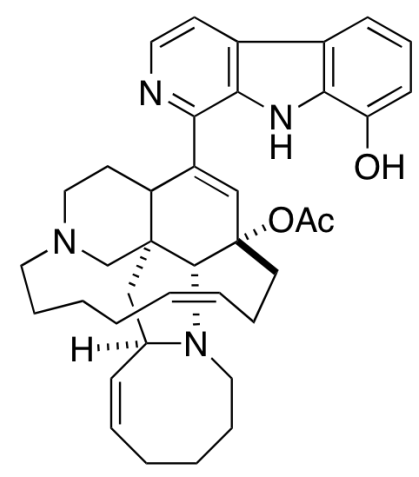

22

Three acetylated 8-hydroxymanzamine A (22) analogues 23, 24 and 25 were prepared by modification at the 8 -position in an effort to generate manzamine prodrugs with improved antimalarial activity and reduced GI toxicity. ${ }^{56}$ These synthetic analogues exhibited antimalarial activity against the chloroquine-sensitive (D6) and the chloroquine-resistant (W2) strains of Plasmodium falciparum with values ranging from 9 to $1300 \mathrm{ng} / \mathrm{mL}$. The most significant in vitro antimalarial activity displayed analogue 23, with an $\mathrm{IC}_{50}=9.6 \mathrm{ng} / \mathrm{mL}$ against the $\mathrm{D} 6$ strain, and $\mathrm{IC}_{50}=30 \mathrm{ng} / \mathrm{mL}$ against the W2 strain, what is comparable to 8-hydroxymanzamine A (22). Analogue 24, which contains acetoxy groups at both the 8- and 12-positions, was the least potent compound, with $\mathrm{IC}_{50}$ values of 1300 and $1200 \mathrm{ng} / \mathrm{mL}$ against the $\mathrm{D} 6$ and $\mathrm{W} 2$ 
clones, respectively. Analogues $\mathbf{2 3}$ and $\mathbf{2 5}$ exhibited toxicity to the normal Vero cell line, while the diacetate $\mathbf{2 4}$ did not show cytotoxicity at the highest tested concentration of $4700 \mathrm{ng} / \mathrm{mL}$. Analogue 23 was also evaluated for in vivo antimalarial activity against Plasmodium berghei sensitive strain, but appeared being rather toxic. ${ }^{56}$ Interesting results of quaternary manzamine derivatives similar to nostocarboline (13) were reported. ${ }^{57}$ All these examples 1-25 support the notion that alkaloids still represent an important class for the discovery of novel antimalarial agents.

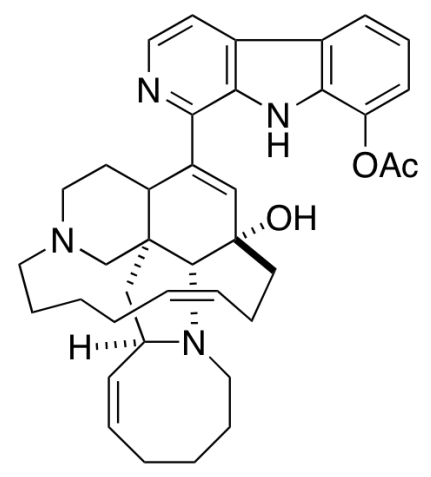

23

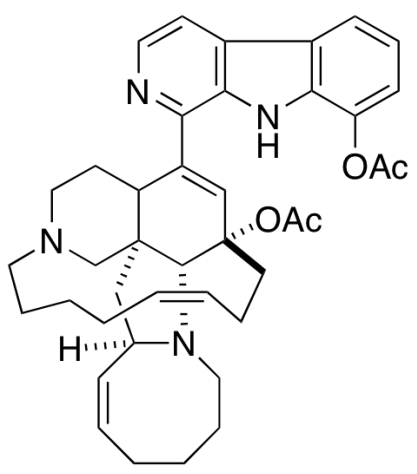

24

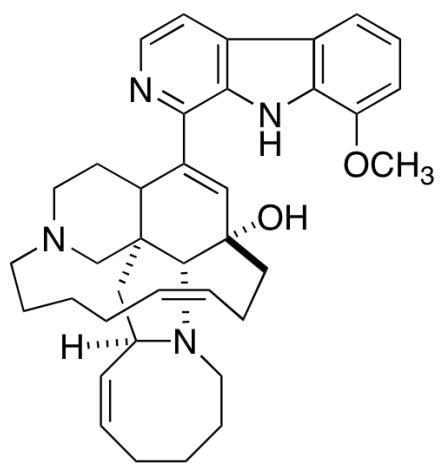

25

Several peptides were isolated over the last years that display antiplasmodial activity. Gerwick and coworkers have recently isolated antimalarial venturamides A (26) and B (27) from a Panamanian Oscillatoria $s p . .{ }^{58}$ These modified cyclic hexapeptides showed moderate selectivity for the parasite versus mammalian host cells. Venturamide A (26) showed in vitro activity against $P$. falciparum $\left(\mathrm{IC}_{50}=8.2 \mu \mathrm{M}\right)$, with only mild cytotoxicity to mammalian Vero cells $\left(\mathrm{IC}_{50}=86 \mu \mathrm{M}\right)$. Venturamide $\mathrm{B}$ (27) also showed low micromolar antimalarial activity against $P$. falciparum $\left(\mathrm{IC}_{50}=\right.$ $5.6 \mu \mathrm{M})$ and mild cytotoxicity to mammalian Vero cells $\left(\mathrm{IC}_{50}=56 \mu \mathrm{M}\right)$. The mode of action of these compounds is yet unknown. 
<smiles></smiles>

26<smiles>Cc1nc([C@@H](C)NC(=O)c2csc([C@@H](NC(=O)c3csc([C@@](NC(=O)c4c[nH]c(C(C)C)n4)(C(C)C)C(C)O)n3)C(C)C)n2)oc1C</smiles>

27

Four new haxacyclopeptides, aerucyclamides $\mathrm{A}^{59}(\mathbf{2 8}), \mathrm{B}^{59}(\mathbf{2 9}), \mathrm{C}^{60}$ (30) and $\mathrm{D}^{60}$ (31) were isolated from cyanobacterium Microcystis aeruginosa PCC 7806 and their structural characterization, synthesis and biological evaluation have been reported. ${ }^{59}$, ${ }^{60}$ These peptides are the actual metabolites produced by ribosomal peptide synthesis in $M$. aeruginosa PCC 7806, it has been predicted by a parallel study. ${ }^{61}$<smiles></smiles>

28<smiles></smiles>

30<smiles>CC[C@H](C)NC(=O)[C@@H](NC(=O)c1csc(C(NC(=O)c2csc(CNC(=O)[C@H]3N=C([C@H](C)CC)O[C@@H]3C)n2)[C@H](C)CC)n1)[C@@H](C)CC</smiles>

29<smiles>CSCCC1NC(=O)C2=CSC(=NNC1=O)CNC(=O)[C@@H]1N=C(O[C@@H]2C)[C@H](Cc2ccccc2)NC(=O)[C@H]2CSC(=N2)[C@@H]1C</smiles>

31

Aerucyclamide A (28) is a rare example of a cyclamide that features oxazoline, thiazoline, and thiazole moieties in one compound. Aerucyclamide B (29) is an oxidative derivative of $\mathbf{2 8}$, and can be obtained synthetically through oxidation of aerucyclamide A (28) $\left(\mathrm{MnO}_{2}\right.$, benzene). Surprisingly, the structure of aerucyclamide 
C (30) matched the one reported for microcyclamide 7806A (32) despite different data. Structure 32 was postulated as the actual metabolite of ribosomal peptide synthesis by Ziemert et al. ${ }^{61}$ Therefore, we suggested a structure revision of microcyclamide 7806A (32), ${ }^{60}$ based on chemical, physical and spectroscopic evidence. The revised structure 33 for microcyclamide $7806 \mathrm{~A}^{60}$ includes an ester involving the Thr group and the ammonium residue instead of the oxazoline ring. Moreover, microcyclamides 7806A (32) and B (34) can be obtained under acidic conditions frequently used in HPLC purifications $(\mathrm{CF} 3 \mathrm{CO} 2 \mathrm{H}$ in $\mathrm{H} 2 \mathrm{O})$ from aerucyclamide $\mathrm{C}$ (30). This chemical transformation supports the hypothesis that both microcyclamides 7806A (32) and B (34) are isolation artifacts, and that the aerucyclamides A-D (28-31) are the actual metabolites produced via ribosomal peptide synthesis in Microcystis aeruginosa PCC $7806 .^{60}$<smiles>CC[C@H](C)[C@H](NC(=O)c1coc(C(NC(=O)[C@H]2N=C(C(C)C)[C@@H](C)NC(=O)c3csc(n3)[C@H]2C)C(C)C)n1)C(C)C</smiles>

Microcylamide 7806A Original Structure (32)<smiles>CC[C@H](C)[C@H](NC(=O)c1coc(C(NC(=O)[C@H](N)[C@@H](C)OC(=O)[C@H](C)NC(=O)c2cscn2)C(C)C)n1)C(C)C</smiles>

Microcylamide 7806A Revised Structure (33)<smiles>CC[C@H](C)[C@H](NC(=O)c1coc(C(NC(=O)[C@H](NC(=O)[C@H](C)O)C(C)C)C(C)C)n1)c1nc(C(=O)N[C@@H](C)C(C)C)cs1</smiles>

Microcylamide 7806B (34)

All four cyclamide derivatives 28-31 were biologically evaluated for antiplasmodial activity. The most active compound was aerucyclamide B (29), displaying a submicromolar $\mathrm{IC}_{50}$ value of $0.7 \mu \mathrm{M}$ against the chloroquine-resistant strain $\mathrm{K} 1$ of Plasmodium falciparum. In addition, this compound displays a large selectivity for the parasite with respect to the L6 rat myoblast cell line, where an $\mathrm{IC}_{50}$ value of 120 $\mu \mathrm{M}$ was determined. Interestingly, a reduction of the thiazole to a thiazoline (structural modification from 29 to 28 ) decreases the antiplasmodial activity by 1 order of magnitude. Similar low micromolar activities displayed aerucyclamides C (30) and $\mathrm{D}(\mathbf{3 1})\left(\mathrm{IC}_{50}=2.3\right.$ and $6.3 \mu \mathrm{M}$, respectively). All compounds displayed very weak (for 29 and 30) or no toxicity to the L6 rat myoblast cell line under the conditions evaluated. Therefore, such cyclamides $\mathbf{2 8 - 3 1}$ as well as venturamides A (26) and B (27) can be considered interesting lead structures for further development.

Gerwick and coworkers reported two other marine cyanobacterial metabolites. ${ }^{62} \mathrm{New}$ 
linear alkynoic lipopetides, dragomabin (35) and dragonamide B (36), have been isolated from a red Panamanian strain of the marine cyanobacterium Lyngbya majuscula from different sites in the Bocas del Toro region. ${ }^{62}$<smiles>C#CCCCCC(C)C(=O)N(C)C(Cc1ccccc1)C(=O)N[C@@H](C)C(=O)N(C)C(C)C(=O)N(C)[C@@H](Cc1ccc(OC)cc1)C(N)=O</smiles><smiles>C#CCCCCC(C)C(=O)N(C)C(C(=O)N(C)[C@H](C(=O)N(C)C(C(=O)N(C)[C@@H](C(N)=O)C(C)C)C(C)C)C(C)C)C(C)C</smiles>

36

Dragomabin (35) showed good antimalarial activity $\left(\mathrm{IC}_{50}=6 \mu \mathrm{M}\right)$ against chloroquine-resistant Plasmodium falciparum, whereas the nonaromatic analogue, dragonamide B (36) was inactive in this assay.

An investigation of a marine cyanobacterium Oscillatoria nigro-viridis from Panama led to the isolation of two novel bioactive lipopeptides, viridamides A (37) and B (38). ${ }^{63}$ Viridamide A (37) was tested against a series of relevant tropical pathogens and cancer cell lines, and it displayed significant activity against the parasitic protozoan $P$. falciparum $\left(\mathrm{IC}_{50}=5.8 \mu \mathrm{M}\right)$, but also displayed strong activity against Trypanosoma cruzi and Leishmania mexicana. 


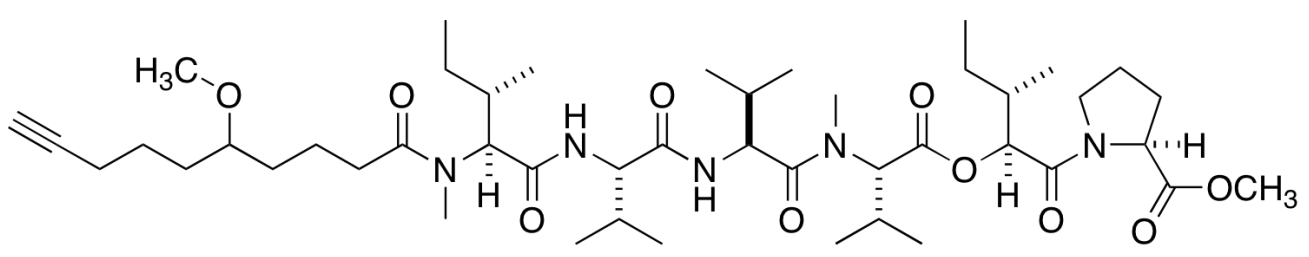

37<smiles>C#CCCCC(CCCC(=O)N(C)C(C(=O)N[C@H](C(=O)NC(C(=O)N(C)[C@H](C(=O)OC(C(=O)N1CCC[C@H]1C(=O)OC)C(C)C)C(C)C)C(C)C)C(C)C)[C@@H](C)CC)C(C)C</smiles>

38

The marine cyanobacterium Blennothrix cantharidosmum was a source for six new acyl proline derivatives, tumonoic acids D-I (39-44), plus the known tumonoic acid A and lyngbyastatins as the active metabolites. ${ }^{64}$ The tumonoic acids were originally isolated from a Lyngbya majuscula / Schizothrix calcicola assemblage, as well as collection of L. majuscula, all collected in Guam, ${ }^{65}$ but phylogenetic investigation using 16S rRNA suggests that these compounds could also originate from Lyngbya/Blennothrix assemblages. The new compounds were tested in an array of assays, but only tumonoic acid I (44) displayed antimalarial activity with an $\mathrm{IC}_{50}=2$ $\mu \mathrm{M}$, none of the other naturally occurring analogues showed any activity in this assay at a concentration of up to $10 \mu \mathrm{g} / \mathrm{mL}$. The target of these compounds is unknown. ${ }^{64}$ 
<smiles>CCCCCCCCC(C)C(=O)N1CCC[C@H]1CO</smiles><smiles>CCCCC(C)/C=C(\C)[C@H](O)C(C)C(=O)N1CCC[C@H]1C(=O)O</smiles>

40<smiles></smiles><smiles>CCCCCCCC(C)C(=O)N1CCC[C@H]1C(=O)O[C@H](C(=O)O[C@@H](C)C(=O)O)[C@@H](C)CC</smiles><smiles>CCCCCCCCC(C)C(=O)N1CCC[C@H]1C(=O)OC(C(=O)OC(C(=O)O)C(C)C)C(C)C</smiles>

43<smiles>[2H]C(OC(=O)[C@@H](C)C(C)OC(=O)[C@@H]1CCCN1C(=O)C(C)CC(C)CCCC)(C(=O)O)[C@@H](C)CC</smiles>

In addition to these peptides, several amino acid derivatives were isolated and characteriyed. Salinosporamide A (45) was initially discovered and described in 2003 by Fenical and co-workers from the marine actinomycete Salinispora tropica ${ }^{66}$ and belongs to a family of compounds possessing a densely functionalized $\gamma$-lactam- $\beta$ lactone bicyclic framework. These compounds are potent anticancer agents due to proteasome inhibition. Compound 45 was evaluated by Prudhomme et al., ${ }^{67}$ who found this lactam $\mathbf{4 5}$ to be a highly potent inhibitor of the human malaria parasite both in vitro $\left(\mathrm{IC}_{50}=11.4 \mathrm{nM}\right.$ ) and in vivo (ca. $90 \%$ reduction in parasitemia at $130 \mu \mathrm{g} / \mathrm{kg}$ (s.c.) in mice, P. yoelii). More promisingly, salinosporamide A (45) is currently in phase I clinical trials against the treatment of refractory multiple myeloma. 


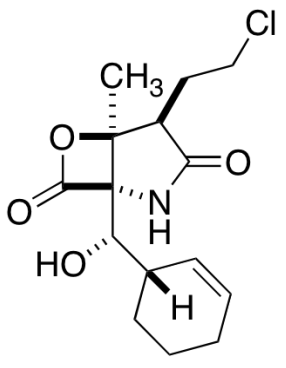

45

Eight compounds, including four new natural products, were isolated from the marine octocoral Muricea austera collected in the Pacific coast of Panama. ${ }^{68}$ Two natural tyramine derivatives, 46 and $\mathbf{4 7}$, showed moderate antiplasmodial activity $\left(\mathrm{IC}_{50}=45\right.$ and $38 \mu \mathrm{M}$ ), and a series of synthetic derivatives with fatty acid moieties showed antiplasmodial activity very similar to those of their natural analogues. ${ }^{68}$<smiles>CCCCCCCCCC(C)CC(=O)NCCc1ccc(O)cc1</smiles><smiles>CC/C=C/C/C=C/C/C=C/CCCC(=O)NCCc1ccc(O)cc1</smiles>

Another class of natural products with antiplasmodial activity encompasses hydroxyaromatic compounds. Three new natural products chaetoxanthones A (48), B (49) and C (50) were isolated from marine-derived fungus Chaetomium sp.. ${ }^{69}$ Compounds 48 and 49 are substituted with a dioxane/tetrahydropyran moiety rarely found in natural products, and compound $\mathbf{5 0}$ was identified as a chlorinated xanthone substituted with a tetrahydropyran ring. The new xanthones were tested in a series of in vitro bioassays for their antiprotozoal activities and cytotoxic potency. Among the isolated xanthones only chaetoxanthone B (49), which was probably isolated as racemate based on $\mathrm{CD}$ spectroscopic evidence, showed selective antiprotozoal activity against $P$. falciparum with an $\mathrm{IC}_{50}=0.5 \mu \mathrm{g} / \mathrm{mL}$ (at least 7.5-fold enhanced potency compared to the other tested protozoans) without being cytotoxic toward cultured eukaryotic L6-cells $\left(\mathrm{IC}_{50}>90 \mu \mathrm{g} / \mathrm{mL}\right)$. The mode of action of xanthones toward Plasmodium parasites was investigated in detail in earlier studies, ${ }^{70,71}$ and 
these compounds are considered to inhibit heme polymerization. Thus, the detoxification of harmful hematin is hampered which results in the death of the parasitic cells. $^{70,71}$<smiles></smiles>

48<smiles>COc1cccc2oc3cc4c(c(O)c3c(=O)c12)[C@@H]1CCC[C@](C)(O4)O1</smiles>

rac-49<smiles>COc1cccc2oc3c(Cl)c(O)c(C4CCCC(C)O4)c(O)c3c(=O)c12</smiles>

Previously described xestoquinone ${ }^{72-80}$ (51) was re-isolated from the marine sponge Xestospongia collected in Vanuatu in South Pacific. ${ }^{36}$ The selectivity of the protein kinase inhibitory activity of xestoquinone against a panel of $P$. falciparum protein kinases was evaluated. ${ }^{81}$ Xestoquinone (51), the most potent and the most abundant Pfnek- $1^{82}$ inhibitor, showed a moderate in vitro antiplasmodial activity against a FCB1 $P$. falciparum strain $\left(\mathrm{IC}_{50}=3 \mu \mathrm{M}\right)$ and exhibited a cytotoxic activity on MCF7 cells with an $\mathrm{IC}_{50}$ value of $20 \mu \mathrm{M}$, but it only exhibited weak in vivo activity at 5 $\mathrm{mg} / \mathrm{kg}$ in Plasmodium berghei NK65 infected mice and was toxic at higher doses.<smiles>CC12CCCc3coc(c31)C(=O)c1cc3c(cc12)C(=O)C=CC3=O</smiles>

51

Four new bioactive compounds, alisiaquinones A, B and C (52, 53 and 54) and alisaquinol (55), were isolated from a New Caledonian deep-water sponge. ${ }^{83}$ They are 
related to xestoquinone $(51),{ }^{76,84}$ methoxyxestoquinone, ${ }^{79}$ adociaquinone $^{80}$ and xestoquinol, ${ }^{39,76,84}$ respectively, but show an unusual substitution pattern on the furan ring. These new meroterpenes displayed mild activity with micromolar range on two enzymatic targets of importance for the control of malaria, the plasmodial kinase Pfnek-1 and a protein farnesyl transferase (PFT) as well as on different chloroquinesensitive and chloroquine-resistant strains of Plasmodium falciparum. ${ }^{83}$ Alisiaquinones A (52) and B (53) and alisiaquinol (55) displayed similar activities in vitro on Plasmodium falciparum, but the $\mathrm{IC}_{50}$ values were not determined on Pfnek-1. Alisiaquinone A (52) was slightly less cytotoxic and had low selectivity index. Alisoquinone C (54), bearing the taurine substituent, displayed a submicromolar activity on Plasmodium falciparum and a competitive selectivity index on the different plasmodial strains, especially on the chloroquine-resistant strain PfFcMC29. For alisaquinones A (52) and C (54) also the in vivo activity was investigated, but they displayed a relatively high level of toxicity.<smiles>C[C@@]12CCC[C@]3(C)C[C@]3(C)COC1(O)C(=O)c1cc3c(cc12)C(=O)C=CC3=O</smiles>

52<smiles></smiles>

54<smiles>COC1=CC(=O)c2cc3c(cc2C1=O)C(=O)C1(O)OC[C@]2(C)CCC[C@]3(C)[C@H]12</smiles>

53<smiles>C[C@]12CCC[C@@]3(C)c4cc5c(O)ccc(O)c5cc4C(=O)C(O)(OC1)[C@H]23</smiles>

55

A new tetronic acid, nodulisporacid A (56), isolated from a marine-derived fungus Nodulisporium sp. CRIF1 exhibited moderate antiplasmodial activity. ${ }^{85}$ This compound was identified as a truncated derivative of lowdenic acid ${ }^{86}$ and a known tetramic acid, vermelhotin (59), obtained from an unidentified fungus CRI247-01 (a member of the order Pleosporoles), ${ }^{85}$ and was previously obtained as a single $E$ isomer from another unidentified fungus. ${ }^{87}$ Both compounds 56 and $\mathbf{5 9}$ revealed 
spontaneous inter-conversion between $E$ - and $Z$-isomers, forming an equilibrium $E / Z$ mixture with the ratio of 1:1 for nodulisporacid $A(\mathbf{5 6})$ and 1:2 for vermelholtin (59). Nodulisporacid A (56), the two synthetic derivatives (57 and 58), as well as vermelhotin (59) exhibited good antiplasmodial activity with $\mathrm{IC}_{50}$ values between 1$10 \mu \mathrm{M}$, with the latter compound displaying moderate cytotoxicity. ${ }^{85}$ Previously, vermelhotin (59) was tested against fungi and bacteria, but it showed no antifungal and antibacterial activities. ${ }^{87}$<smiles>CCC(C)C[C@]1(C)C=CC(=C2C(=O)O[C@@H](CC(=O)O)C2=O)O1</smiles>

$(E)$-isomer

$$
56 \mathrm{R}=\mathrm{H}
$$

(Z)-isomer

$57 \mathrm{R}=\mathrm{CH}_{3}$<smiles>CCC(C)C[C@]1(C)CCC(=C2C(=O)O[C@@H](CC(=O)O)C2=O)O1</smiles>

$(E)$-isomer

58<smiles>CCC(C)C[C@]1(C)CC/C(=C2\C(=O)O[C@@H](CC(=O)O)C2=O)O1</smiles><smiles>C/C=C/C1=CC=C/C(=C2\C(=O)CNC2=O)O1</smiles>

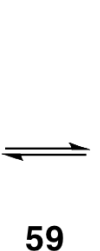

(Z)-isomer<smiles>C/C=C/C1=CC=CC(=C2C(=O)CNC2=O)O1</smiles>

(Z)-isomer

Natural products are prime candidates for the synthesis of analogues, which might be more effective and less toxic than the parent natural products. A series of semisynthetic derivatives ${ }^{88}$ of a remarkably simple 1,2-dioxane derivative, plakortin (60) was prepared. Plakortin (60) itself was isolated from the Caribbean sponge Plakortis simplex, and together with its 9,10-dihydro analogue 61, and two other analogues 3-epiplakortin (62) and plakortide Q (63) display submicromolar activities in vitro against chloroquine-resistant strains of $P$. falciparum. ${ }^{89-91}$ 
<smiles>CC/C=C/C(CC)CC1(C)CC(CC)C(CC(=O)OC)OO1</smiles>

60<smiles>CC/C=C/C(CC)CC1(C)CC(CC)[C@@H](CC(=O)OC)OO1</smiles>

62<smiles>CCCCC(CC)CC1(C)CC(CC)C(CC(=O)OC)OO1</smiles>

61<smiles>CC/C=C/C(CC)CC1(CC)CC(CC)[C@@H](CC(=O)OC)OO1</smiles>

63

The authors ${ }^{88}$ confirmed the crucial role of the endoperoxide functionality in the antimalarial activity of plakortin derivatives, since diol (64) was completely ineffective. The reduction of the ester function to the corresponding hydroxy (65), methoxy (66) or acetoxy (67) derivatives did not affect activity and selectivity for the tested strains of Plasmodium falciparum. A much more pronounced effect on the antimalarial activity are imparted by changes on the alkyl side chain. ${ }^{88}$<smiles>CC/C=C/C(CC)CC(C)(O)CC(CC)C(O)CC(=O)OC</smiles>

64<smiles>[R]OCC1OOC(C)(CC(C=CCC)CC)CC1CC</smiles>

$65 \mathrm{R}=\mathrm{H}$

$66 \mathrm{R}=\mathrm{CH}_{3}$ $67 \mathrm{R}=\mathrm{COCH}_{3}$

The biologically active marine sesquiterpene phenol (S)-(+)-curcuphenol (68) has been isolated from the Jamaican sponges Didiscus oxeata, Didiscus flavus, Myrmekioderma styx and Epipolasis sp. ${ }^{92-94}$ The compound display in vitro antimalarial activity against $P$. falciparum, chloroquine-resistant $\mathrm{W} 2$ clone, with an $\mathrm{IC}_{50}=16.5 \mu \mathrm{M},{ }^{92}$ but it has no antimalarial activity against the chloroquine-sensitive D6 clone.<smiles>CC(C)=CCCC(C)c1ccc(C)cc1O</smiles> 
Hamann et al. ${ }^{95}$ reported the preparation and evaluation for activity against several infectious diseases, of twenty semisynthetic analogues of $(S)-(+)$-curcuphenol (68). They were prepared in yields greater than $90 \%$ by esterification of $(S)-(+)$ curcuphenol (68) with a variety of carboxylic acids in a presence of $\mathrm{N}, \mathrm{N}$ 'dicyclohexylcarbodiimide (DCC) or 4-dimethylaminopyridine (DMAP). There was significant increase in activity against W2 clones in nine analogues of general structure 69 and $\mathrm{IC}_{50}=1.6 \mu \mathrm{M}$ for 70 and 71 was measured, but no increase in activity against the D6 clone was observed.<smiles>[R]C(=O)Oc1cc(C)ccc1C(C)CCC=C(C)C</smiles><smiles>CC(C)=CCCC(C)c1ccc(C)cc1OC(=O)C1CCC(=O)N1</smiles><smiles>CC(C)=CCCC(C)c1ccc(C)cc1OC(=O)c1ccccc1</smiles>

$\mathrm{R}=$ Heteroaryl

Total syntheses of the 2-pyrone-containing marine microbial metabolites pseudopyronines A (72) and B (73), recently reported as weak antibiotics, ${ }^{96,97}$ as well as a number of analogues have been achieved via a methodology based upon the condensation of $\beta$-oxo carboxylic acids. ${ }^{98}$ The compounds $\mathbf{7 2}$ and $\mathbf{7 3}$ were originally isolated from fermentation of Pseudomonas sp. F92S91, which was itself isolated from a sponge collected in Fiji.

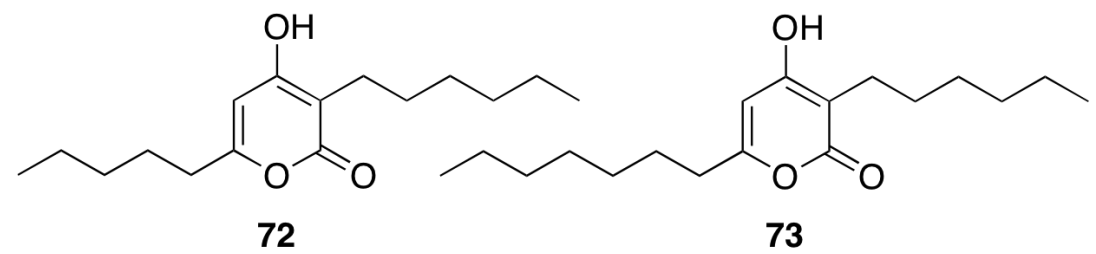

Fatty acids (FAs) are essential for all living organisms, they play crucial roles in the function and viability of cells providing components for biological membranes, acting as chemicals messengers and facilitating the storage of energy. Both natural products, 72 and 73, inhibited PfFabI, the enoyl-ACP-reductase of $P$. falciparum with $\mathrm{IC}_{50}=12$ and $4 \mu \mathrm{g} / \mathrm{mL}$, respectively and additionally pseudopyronine B (72) inhibited PfFabG, 
a $\beta$-ketoacyl-ACP-reductase. The enzyme inhibitory activities of compounds $\mathbf{7 2}$ and 73 were well correlated with their in vitro growth inhibitory potential on $P$. falciparum whole cells, providing evidence that the PfFab pathway may be the potential cellular target of these compounds. ${ }^{98}$

Several carbohydrates or glycosylated structures were also reported in the literature. Glycosides 74 and 77, showed moderate antiplasmodial activity $\left(\mathrm{IC}_{50}=67\right.$ and 80 $\mu \mathrm{M})$, which could be somewhat increased in the triacetylated derivative $\mathbf{7 6}\left(\mathrm{IC}_{50}=28\right.$ $\mu \mathrm{M}){ }^{68}$

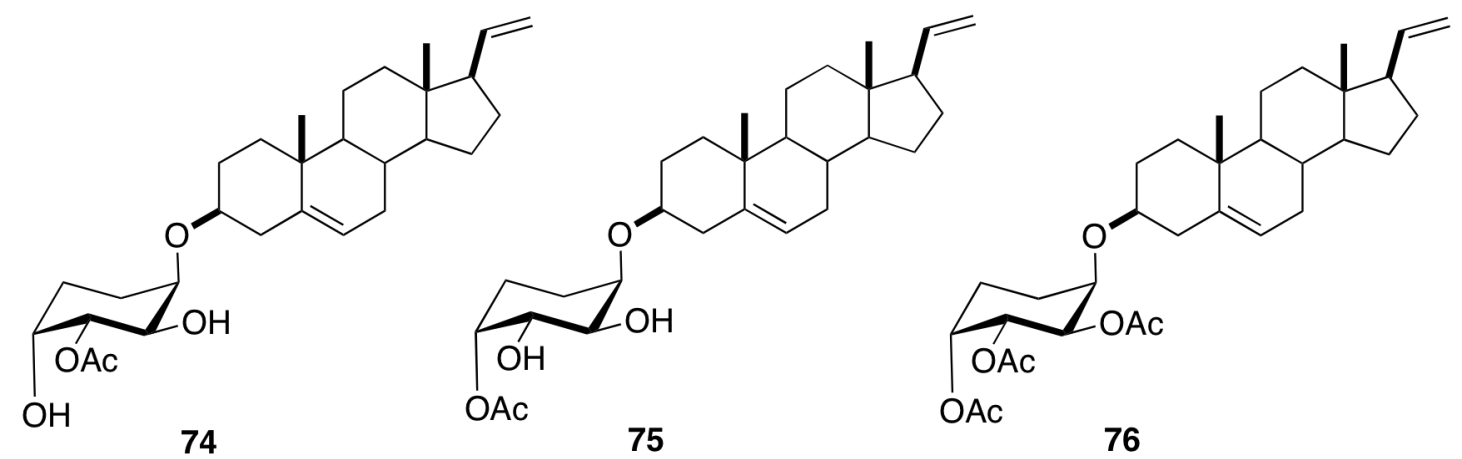

The same authors ${ }^{68}$ synthesized and evaluated the antiplasmodial activity of a series of arabinopyranosides, where two compounds, 77 and $78\left(\mathrm{IC}_{50}=35\right.$ and $\left.21 \mu \mathrm{M}\right)$, were found to be active against Plasmodium falciparum, and were found being more active than the natural arabinopyranosides $\mathbf{7 4}$ and 75. Antiplasmodial activity was also reported for simple sugar derivatives, with the same configuration as that of Darabinopyranose, such as the D-fucosides 79 and $80\left(\mathrm{IC}_{50}=43\right.$ and $\left.36 \mu \mathrm{M}\right)$ and Dgalactoside $81\left(\mathrm{IC}_{50}=21 \mu \mathrm{M}\right)$.
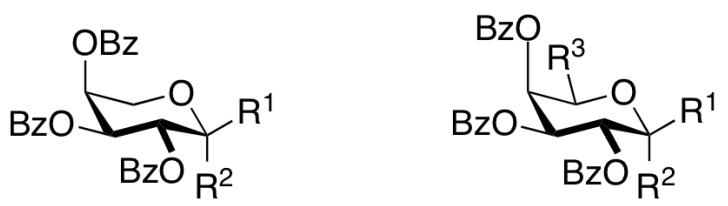

$77 \mathrm{R}^{1}=\mathrm{H} ; \mathrm{R}^{2}=\mathrm{OCH}_{3}$ $78 \mathrm{R}^{1}=\mathrm{OCH}_{3} ; \mathrm{R}^{2}=\mathrm{H}$

$79 \mathrm{R}^{1}=\mathrm{H} ; \mathrm{R}^{2}=\mathrm{OMe} ; \mathrm{R}^{3}=\mathrm{CH}_{3}$ $80 \mathrm{R}^{1}=\mathrm{OCH}_{3} ; \mathrm{R}^{2}=\mathrm{H} ; \mathrm{R}^{3}=\mathrm{CH}_{3}$ $81 \mathrm{R}^{1}=\mathrm{H} ; \mathrm{R}^{2}=\mathrm{OCH}_{3} ; \mathrm{R}^{3}=\mathrm{CH}_{2} \mathrm{OBz}$

A new antimalarial polyether type metabolite $\mathbf{8 2}$ was isolated from the marine microorganism Streptomyces sp. H668. ${ }^{99}$ The antimalarial activity of $\mathbf{2 8}$ was 
evaluated against both the chloroquine-susceptible (D6) and chloroquine-resistant (W2) clones of $P$. falciparum. Compound showed in vitro antiprotozoal activity with $\mathrm{IC}_{50}$ values ranging from 100 to $200 \mathrm{ng} / \mathrm{mL}$ without significant cytotoxicity to Vero cells. The polyether metabolite $\mathbf{8 2}$ is also rather specific to the parasite displaying no toxicity at $4.75 \mu \mathrm{g} / \mathrm{mL}$.

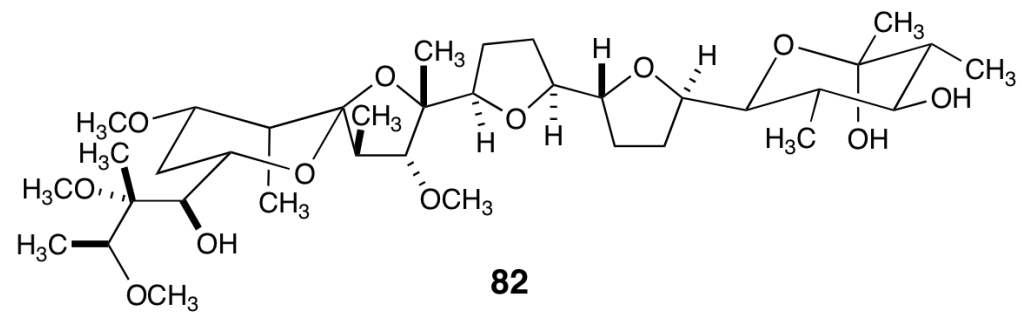

\section{Conclusion}

The present review highlighted various efforts on antimalarial agents that have been documented over the last three years thus clearly demonstrating the high scientific activity of the field. Many new interesting lead structures have been discovered, and valuable structure/activity information has been gathered through total or semisynthesis. Some compounds are currently evaluated in the clinic, and it is hoped that more efficient marine natural products will join the fight against malaria in the future.

\section{Acknowledgments}

K. G. is a European Young Investigator and thanks the Swiss National Science Foundation for support (PE002-117136/1). We thank our colleagues D. Barbaras, C. Portmann (EPFL), Dr. M. Kaiser, Prof. Dr. R. Brun (Swiss Tropical Institute), Dr. J. F. Blom and Prof. Dr. F. Jüttner (University of Zürich) for exciting ventures into the discovery of new antimalarial agents and are looking forward to more fascinating structures and powerful bioactivities. 


\section{References}

[1] http://www.who.int/neglected diseases/en/ (accessed January 20 th , 2009)

[2] M. F. Penet, F. Kober, S. Confort-Gouny, Y. Le Fur, C. Dalmasso, N. Coltel, A. Liprandi, J. M. Gulian, G. E. Grau, P. J. Cozzone, A. Viola, J Biol Chem 2007, 282, 14505-14514.

[3] (a) R. W. Snow, C. A. Guerra, A. M. Noor, H. Y. Myint, S. I. Hay, Nature 2005, 434, 214-217; (b) D. R. Bell, P. Jorgensen, E. M. Christophel, K. L. Palmer, Nature 2005, 437, E3-E4.

[4] S. K. Mishra, S. K. Satpathy, S. Mohanty, Bull World Health Organ 1999, 77, 1020.

[5] M. Plebanski, E. Locke, J. W. Kazura, R. L. Coppel Trends in Parasitology 2008, 24, 532-536.

[6] M. Schlitzer, Chemmedchem 2007, 2, 944-986.

[7] M. Schlitzer, Archiv Der Pharmazie 2008, 341, 149-163.

[8] I. J. Gonzalez, R. E. Varela, C. Murillo, B. E. Ferro, J. Salas, L. E. Giraldo, M. G. Zalis, N. G. Saravia, Trans R Soc Trop Med Hyg 2003, 97, 318-324.

[9] P. Piola, C. Fogg, F. Bajunirwe, S. Biraro, F. Grandesso, E. Ruzagira, J. Babigumira, I. Kigozi, J. Kiguli, J. Kyomuhendo, L. Ferradini, W. Taylor, F. Checchi, J. P. Guthmann, Lancet 2005, 365, 1467-1473.

[10] J. W. Blunt, B. R. Copp, M. H. G. Munro, P. T. Northcote, M. R. Prinsep, Nat Prod Rep 2006, 23, 26-78.

[11] D. J. Faulkner, Nat Prod Rep 2000, 17, 1-6.

[12] D. J. Faulkner, Nat Prod Rep 2001, 18, 1-49.

[13] D. J. Faulkner, Nat Prod Rep 2002, 19, 1-48.

[14] R. A. Hill, Annu Rep Prog Chem, Sect. B 2006, 102, 123-137.

[15] D. Laurent, F. Pietra, Mar Biotechnol 2006, 8, 433-447.

[16] P. Bhadury, B. T. Mohammad, P. C. Wright, J Ind Microbiol Biot 2006, 33, 325-337.

[17] R. R. Brutkiewicz, J Immunol 2006, 177, 769-775.

[18] J. W. Blunt, B. R. Copp, W. P. Hu, M. H. G. Munro, P. T. Northcote, M. R. Prinsep, Nat Prod Rep 2007, 24, 31-86.

[19] S. Ravichandran, K. Kathiresan, H. Balaram, Biotechnol Mol Biol Rev 2007, 2, 33-38.

[20] A. M. S. Mayer, A. D. Rodriguez, R. G. S. Berlinck, M. T. Hamann, Comp Biochem Physiol C-Toxicol Pharmacol 2007, 145, 553-581.

[21] Y. Nakao, N. Fusetani, J Nat Prod 2007, 70, 689-710.

[22] (a) A. M. S. Mayer, K. R. Gustafson, Eur J Canc 2006, 42, 2241-2270; (b) A. M. S. Mayer, K. R. Gustafson, Eur J Canc 2008, 44, 2357-2387.

[23] N. M. Carballeira, J Lip Res 2008, 47, 50-61.

[24] J.-R. Ioset, Curr Org Chem 2008, 12, 643-666.

[25] J. Mendiola, H. Hernandez, I. Sariego, L. Rojas, A. Otero, A. Ramirez, M. D. Chavez, J. A. Payrol, A. Hernandez, T Roy Soc Trop Med H 2006, 100, 909916.

[26] (a) J. Appenzeller, G. Mihci, M.-T. Martin, J.-F. Gallard, J.-L. Menou, N. Boury-Esnault, J. Hooper, S. Petek, S. Chevalley, A. Valentin, A. Zaparucha, A. Al-Mourabit, C. Debitus, J Nat Prod 2008, 71, 1451-1454; (b) H. M. Wu, H. Nakamura, J. Kobayashi, M. Kobayashi, Y. Ohizumi, Y. Hirata, Bull Chem Soc Jpn 1986, 59, 2495-2504.

[27] J. E. H. Lazaro, J. Nitcheu, N. Mahmoudi, J. A. Ibana, G. C. Mangalindan, G. P. Black, A. G. Howard-Jones, C. G. Moore, D. A. Thomas, D. Mazier, C. M. 
Ireland, G. P. Concepcion, P. J. Murphy, B. Diquet, J Antibiot 2006, 59, 583590.

[28] E. A. Jares-Erijman, R. Sakai, K. L. Rinehart, J Org Chem 1991, 56, $5712-$ 5715.

[29] W. Gul, N. L. Hammond, M. Yousaf, J. J. Bowling, R. F. Schinazi, S. S. Wirtz, G. de Castro Andrews, C. Cuevas, M. T. Hamann, Bioorg Med Chem 2006, 14, 8495-8505.

[30] S. Fedoreev, N. Prokofeva, V. Denisenko, N. Rebachuk, Khim Farm Zh 1988, 22, 943.

[31] Y. Kashman, A. Rudi, S. Hirsh, S. Isaacs, D. Green, D. Blasberger, S. Carmely, New J Chem 1990, 14, 729-740.

[32] Y. Shen, C. Chein, P. Hsieh, C. Duh, Taiwan Shuichan Xuehuikan 1997, 24, 117.

[33] G. R. Pettit, H. Hoffmann, J. McNulty, K. C. Higgs, A. Murphy, D. J. Molloy, D. L. Herald, M. D. Williams, R. K. Pettit, D. L. Doubek, J. N. A. Hooper, L. Albright, J. M. Schmidt, J. C. Chapuis, L. P. Tackettt, J Nat Prod 2004, 67, 506-509.

[34] D. Tasdemir, B. Topaloglu, R. Perozzo, R. Brun, R. O`Neill, N. M. Carballeira, X. Zhang, P. J. Tonge, A. Linden, P. Rüedi, Bioorgan Med Chem 2007, 15, 6834-6845.

[35] R. Perozzo, M. Kuo, A. B. S. Sidhu, J. T. Valiyaveettil, R. Bittman, W. R. Jacobs, D. A. Fidock, J. C. Sacchettini, J Biol Chem 2002, 277, 13106-13114.

[36] L. S. Pidugu, M. Kapoor, N. Surolia, A. Surolia, K. Suguna, J Mol Biol 2004, 343, 147-155.

[37] G. M. König, A. D. Wright, A. Linden, Planta Med 1998, 64, 443-447.

[38] R. Mohammed, J. Peng, M. Kelly, M. T. Hamann, J Nat Prod 2006, 69, 17391744.

[39] F. Benoit-Vical, M. Salery, P. N. Soh, A. Ahond, C. Poupat, Planta Med 2008, 74, 438-444.

[40] A. Ahond, M. Bedoya Zurita, M. Colin, C. Fizames, P. Laboute, F. Lavelle, CR Acad Sci Paris 1988, 307, 145-148.

[41] F. Lavelle, A. Zerial, C. Fizames, B. Rabault, A. Curaudeau, Invest New Drug 1991, 9, 233-244.

[42] G. Catimel, R. Coquard, J. P. Guastalla, Y. Merrouche, N. Lebail, M. K. Alakl, A. Dumortier, M. Foy, M. Clavel, Cancer Chemoth Pharm 1995, 35, 246-248.

[43] G. Colson, B. Rabault, F. Lavelle, A. Zerial, Biochem Pharmacol 1992, 43, 1717-1723.

[44] S. Tsukamoto, K. Tane, T. Ohta, S. Matsunaga, N. Fusetani, R. W. Van Soest, J Nat Prod 2001, 64, 1576-1578.

[45] P. G. Becher, J. Beuchat, K. Gademann, F. Jüttner, J Nat Prod 2005, 68, 1793.

[46] J. F. Blom, T. Brutsch, D. Barbaras, Y. Bethuel, H. H. Locher, C. Hubschwerlen, K. Gademann, Org Lett 2006, 8, 737-740.

[47] P. G. Becher, H. I. Baumann, K. Gademann, F. Jüttner, J Appl Phycol 2009, 21, 103-110.

[48] D. Barbaras, M. Kaiser, R. Brun, K. Gademann, Bioorg Med Chem Lett 2008, $18,4413-4415$.

[49] R. Sakai, T. Higa, J Am Chem Soc 1986, 108, 6404-6405.

[50] J. F. Hu, M. T. Hamann, R. T. Hill, M. Kelly, The Alkaloids 2003, 60, 207285. 
[51] M. Yousaf, N. L. Hammond, J. N. Peng, S. Wahyuono, K. A. McIntosh, W. N. Charman, A. M. S. Mayer, M. T. Hamann, J Med Chem 2004, 47, 3512-3517.

[52] K. K. H. Ang, M. J. Holmes, T. Higa, M. T. Hamann, U. A. K. Kara, Antimicrob Agents Ch 2000, 44, 1645-1649.

[53] M. Tsuda, J. Kobayashi, Heterocycles 1997, 46, 765-794.

[54] T. Ichiba, J. M. Corgiat, P. J. Scheuer, M. Kellyborges, J Nat Prod 1994, 57, 168-170.

[55] K. V. Rao, B. D. Santarsiero, A. D. Mesecar, R. F. Schinazi, B. L. Tekwani, M. T. Hamann, J Nat Prod 2003, 66, 823-828.

[56] A. G. Shilabin, N. Kasanah, B. L. Tekwani, M. T. Hamann, J Nat Prod 2008, $71,1218-1221$.

[57] M. A. Ibrahim, A. G. Shilabin, S, Prasanna, M. Jacob, S. I. Khan, R. J. Doerksen, M. T. Hamann, Bioorg. Med. Chem. 2008, 16, 6702-6706.

[58] R. G. Linington, J. Gonzalez, L. D. Urena, L. I. Romero, E. Ortega-Barria, W. H. Gerwick, J Nat Prod 2007, 70, 397-401.

[59] C. Portmann, J. F. Blom, K. Gademann, F. Jüttner, J Nat Prod 2008, 71, 1193 1196.

[60] C. Portmann, J. F. Blom, M. Kaiser, R. Brun, F. Jüttner, K. Gademann, J Nat Prod 2008, 71, 1891-1896.

[61] N. Ziemert, K. Ishida, P. Quillardet, C. Bouchier, C. Hertweck, N. T. de Marsac, E. Dittmann, Appl Environ Microbiol 2008, 74, 1791-1797.

[62] K. L. McPhail, J. Correa, R. G. Linington, J. Gonzalez, E. Ortega-Barria, T. L. Capson, W. H. Gerwick, J Nat Prod 2007, 70, 984-988.

[63] T. L. Simmons, N. Engene, L. D. Urena, L. I. Romero, E. Ortega-Barria, L. Gerwick, W. H. Gerwick, J Nat Prod 2008, 71, 1544-1550.

[64] B. R. Clark, N. Engene, M. E. Teasdale, D. C. Rowley, T. Matainaho, F. A. Valeriote, W. H. Gerwick, J Nat Prod 2008, 71, 1530-1537.

[65] G. G. Harrigan, H. Luesch, W. Y. Yoshida, R. E. Moore, D. G. Nagle, J. Biggs, P. U. Park, V. J. Paul, J Nat Prod 1999, 62, 464-467.

[66] R. H. Feling, G. O. Buchanan, T. J. Mincer, C. A. Kauffman, P. R. Jensen, W. Fenical, Angew Chem Int Edit 2003, 42, 355-357.

[67] J. Prudhomme, E. McDaniel, N. Ponts, S. Bertani, W. Fenical, P. Jensen, K. Le Roch, Plos One 2008, 3, 2335-2342.

[68] M. Gutierrez, T. L. Capson, H. M. Guzman, J. Gonzalez, E. Ortega-Barria, E. Quinoa, R. Riguera, J Nat Prod 2006, 69, 1379-1383.

[69] A. Pontius, A. Krick, S. Kehraus, R. Brun, G. M. König, J Nat Prod 2008, 71, 1579-1584.

[70] C. Portela, C. M. M. Afonso, M. M. M. Pinta, M. J. Ramos, Bioorgan Med Chem 2004, 12, 3313-3321.

[71] M. V. Ignatushchenko, R. W. Winter, H. P. Bachinger, D. J. Hinrichs, M. K. Riscoe, FEBS Lett 1997, 409, 67-73.

[72] R. H. Lee, D. L. Slate, R. Moretti, K. A. Alvi, P. Crews, Biochem Bioph Res Co 1992, 184, 765-772.

[73] K. A. Alvi, J. Rodriguez, M. C. Diaz, R. Moretti, R. S. Wilhelm, R. H. Lee, D. L. Slate, P. Crews, J Org Chem 1993, 58, 4871-4880.

[74] S. G. Cao, C. Foster, M. Brisson, J. S. Lazo, D. G. I. Kingston, Bioorgan Med Chem 2005, 13, 999-1003.

[75] H. Fujiwara, K. Matsunaga, M. Saito, S. Hagiya, K. I. Furukawa, H. Nakamura, Y. Ohizumi, Eur J Pharmacol 2001, 413, 37-45. 
[76] H. Nakamura, J. Kobayashi, M. Kobayashi, Y. Ohizumi, Y. Hirata, Chem Lett 1985, 713-716.

[77] M. Kobayashi, H. Nakamura, J. Kobayashi, Y. Ohizumi, J Pharmacol Exp Ther 1991, 257, 82-89.

[78] M. Kobayashi, A. Muroyama, H. Nakamura, J. Kobayashi, Y. Ohizumi, J Pharmacol Exp Ther 1991, 257, 90-94.

[79] G. P. Concepcion, T. A. Foderaro, G. S. Eldredge, E. Lobkovsky, J. Clardy, L. R. Barrows, C. M. Ireland, J Med Chem 1995, 38, 4503-4507.

[80] F. J. Schmitz, S. J. Bloor, J Org Chem 1988, 53, 3922-3925.

[81] D. Laurent, V. Jullian, A. Parenty, M. Knibiehler, D. Dorin, S. Schmitt, O. Lozach, N. Lebouvier, M. Frostin, F. Alby, S. Maurel, C. Doerig, L. Meijer, M. Sauvain, Bioorgan Med Chem 2006, 14, 4477-4482.

[82] D. Dorin, K. Le Roch, P. Sallicandro, P. Alano, D. Parzy, P. Poullet, L. Meijer, C. Doerig, Eur J Biochem 2001, 268, 2600-2608.

[83] D. Desoubzdanne, L. Marcourt, R. Raux, S. Chevalley, D. Dorin, C. Doerig, A. Valentin, F. Ausseil, C. Debitus, J Nat Prod 2008, 71, 1189-1192.

[84] N. Harada, T. Sugioka, H. Uda, T. Kuriki, J Org Chem 1990, 55, 3158-3163.

[85] C. Kasettrathat, N. Ngamrojanavanich, S. Wiyakrutta, C. Mahidol, S. Ruchirawat, P. Kittakoop, Phytochemistry 2008, 69, 2621-2626.

[86] R. F. Angawi, D. C. Swenson, J. B. Gloer, D. T. Wicklow, J Nat Prod 2003, 66, 1259-1262.

[87] T. Hosoe, K. Fukushima, K. Takizawa, T. Itabashi, K. Yoza, K. Kawai, Heterocycles 2006, 68, 1949-1953.

[88] C. Fattorusso, G. Campiani, B. Catalanotti, M. Persico, N. Basilico, S. Parapini, D. Taramelli, C. Campagnuolo, E. Fattorusso, A. Romano, O. Taglialatela-Scafati, J Med Chem 2006, 49, 7088-7094.

[89] F. Cafieri, E. Fattorusso, O. Taglialatela-Scafati, A. Ianaro, Tetrahedron 1999, 55, 7045-7056.

[90] E. Fattorusso, S. Parapini, C. Campagnuolo, N. Basilico, O. TaglialatelaScafati, D. Taramelli, J Antimicrob Chemother 2002, 50, 883-888.

[91] C. Campagnuolo, E. Fattorusso, A. Romano, O. Taglialatela-Scafati, N. Basilico, S. Parapini, D. Taramelli, Eur J Org Chem 2005, 5077-5083.

[92] K. A. El Sayed, M. Yousaf, M. T. Hamann, M. A. Avery, M. Kelly, P. Wipf, J Nat Prod 2002, 65, 1547-1553.

[93] J. Peng, S. G. Franzblau, F. Zhang, M. T. Hamann, Tetrahedron Lett 2002, 43, 9699-9702.

[94] (a) A. E. Wright, S. A. Pomponi, O. J. Mcconnell, S. Kohmoto, P. J. Mccarthy, J Nat Prod 1987, 50, 976-978; (b) N. Fusetani, M. Sugano, S. Matsunaga, K. Hashimoto, Experientia 1987, 43, 1234-1235.

[95] W. Gul, N. L. Hammond, M. Yousaf, J. Peng, A. Holley, M. T. Hamann, Biochim Biophys Act 2007, 1770, 1513-1519.

[96] M. P. Singh, F. Kong, J. E. Janso, D. A. Arias, P. A. Suarez, V. S. Bernan, P. J. Petersen, W. J. Weiss, G. Carter, M. Greenstein, J Antibiot 2003, 56, 10331044.

[97] F. M. Kong, M. P. Singh, G. T. Carter, J Nat Prod 2005, 68, 920-923.

[98] A. C. Giddens, L. Nielsen, H. I. Boshoff, D. Tasdemir, R. Perozzo, M. Kaiser, F. Wang, J. C. Sacchettini, B. R. Copp, Tetrahedron 2008, 64, 1242-1249.

[99] M. Na, D. A. F. Meujo, D. Kevin, M. T. Hamann, M. Anderson, R. T. Hill, Tetrahedron Lett 2008, 49, 6282-6285. 